\begin{abstract}
Татјана M. Самарџија ${ }^{*}$ https://doi.org/10.18485/ai_vnia_bora_djordjevic.2018.1.10 Универзитет у Београду

Филолошки факултет у Београду

Катедра за романистику

\title{
ПОСТОЈИ ЈЕДНО ОСТРВО - ЉУБАВ У ПОЕЗИЈИ БОРЕ ЂОРЪЕВИЋА И РОМАНИМА МИШЕЛА ВЕЛБЕКА
}

Поређењем љубавне поезије Боре Ђорђевића и романа Мишела Велбека, с посебним нагласком на њиховим делима сличног наслова - Пусто острво Боре Ђорђевића и Могућност острва Мишела Велбека - показујемо бројне сличности у њиховом приступу парадоксу љубавне патње, који спаја снажну љубав-потребу с изостанком љубави-дара. На основу трију дихотомија - ерос/агапе (Denis de Rougemont, L'Amour et l'Occident, 1972), љубав-потреба/ љубав-дар (C. S. Lewis, The Four Loves, 1960) и ја-ти/ ја-оно (Martin Buber, Ich und Du, 1923) - настојимо да покажемо како оба писца виде старење, егоцентризам и романтичну илузију као основне препреке за постојаност љубави. Посебно се осврћемо на мотиве острва и пса, као и на теме еротске љубави, старости и романтичне илузије.

Кључне речи: острво, ерос, агапе, Бора Ђорђевић, Мишел Велбек, Дени де Ружмон, К. С. Луис.

\section{1. Увод}

Ако је повод за овај напис збирка Пусто острво, која је Бори Ђорђевићу донела Велику Андрићеву награду,

* tatjana.g.samardzija@gmail.com. 
његов дубоки разлог јесте читав низ раније уочених сличности, не само двају наслова - Могућност острва (Велбек, 2005) и Пусто острво (Ђорђевић, 2018) - већ и многобројних тематских и мотивских повезница између љубавне поезије Боре Ђорђевића и романсијерског опуса Мишела Велбека, неоспорно најбољег француског писца данашњице. Упоредна анализа неких заједничких тема, мотива и концепата биће извршена у два дела.

У првом делу поставићемо теоријски и концептуални оквир у ком ће се кретати наша анализа. Полазна тачка биће дихотомија између љубави-ероса и љубави-агапеа у делу Љубав и Запад (L'Amour et l'Occident, 1972; прев. 2011) швајцарског филозофа Денија де Ружмона (1906-1885). Ова дихотомија израња из анализе мита о Тристану и Изолди, као и његових средњовековних, романтичарских и савремених књижевних и филмских аватара. Друга дихотомија иде много даље и дубље: у студији Четири тьубави (The Four Loves, 1960; хрв. превод 2012), К. С. Луис (1898-1963) разликује љубав-потребу, којом нпр. дете воли мајку или човек Бога, од љубави-дара, којом мајка воли дете или Бог човека. Премда реч дихотомија дословно означава расецање на двоје, Луис ће заправо, за разлику од Ружмона, помирити љубав-потребу и љубав-дар у комплементарно јединство. Коначно, накратко ћемо се дотаћи дихотомије коју, на темељу свог „дијалошког принципа”, Мартин Бубер (1868-1965) предлаже у делу Ich und Du.

У другом делу рада циљ нам је да Ружмонову, Буберову и Луисову дихотомију применимо на неке теме, мотиве и концепте који повезују љубавну поезију Боре Ђорђевића и романе Мишела Велбека. Показаће се да оба аутора веома слично анализирају мед и жуч љубави, а нарочито трагични несклад између људског егоизма и потребе за љубављу, између биолошког старења и доживотне менталне и емотивне сексуалности, што рађа самоћу и бол 
остављених. Обојица главни део опуса посвећују еросу (љубави-потреби), а знатно мањи агапеу (љубави-дару), с изузетком Ђорђевићевог Пустог острва.

Овај рад не посвећујемо ретким срећницима у љубави, већ несрећној већини мушкараца и жена који и које не умеју да воле.

\section{2. Љубавне дихотомије Д. де Ружмона, К. С. Луиса и М. Бубера}

Једна од најлепших и највољенијих песама Десанке Максимовић несумњиво је „Стрепња”, чије делове наводимо:

„Не, немој ми прићи! Хоћу издалека / да волим и желим ока твоја два. / Јер срећа је лепа само док се чека, [...] Све је много лепше донде док се тражи, / о чему се само тек по слутњи зна. [...] издалека само дивимо се свему./ Не, нек' ми не приђу ока твоја два."

Зашто је „срећа лепа само док се чека”? Зашто „издалека само дивимо се свему"? Зар није лепше живети заједно? Открити другог? Или близина представља неку скривену опасност за љубав, која може окрњити „ову слатку стрепњу, чекање и стра"'?

\section{1. љубав-ерос}

Један од могућих одговора на ово питање пружио је Ружмон у студији љубав и Запад. На темељу анализе приповести о Тристану и Изолди као мита о фаталној страсти - чије келтско порекло и гностички религијско-филозофски оквир сједињују Запад и Исток Ружмон супротставља љубав-ерос, „љубавну сиротињу” 
оличену у страсти између Тристана и Изолде, и љубав-агапе, „богату” љубав која се даје.

Ружмон показује како концепт куртоазне љубави (finamor или amour courtois) у средњем веку уводи један нови ауторитет у односу на сизерена - то је љубљена госпа. Ако је, дакле, сизерен господар коме се у материјалном свету потчињава муж-витез, куртоазна љубав представља закон „духовног света” којим влада госпа, којој се потчињава љубавник. Нарочито трубадурска поезија, али и куртоазна уметност уопште, приказује искушења (assag, assay) којима је изложен витез да би био достојан даме коју воли. Рене Нели, велики стручњак за катаризам и трубадурску поезију, објашњава природу једног таквог искушења:

„Assag је представљао искушење током ког је драган морао показати да је кадар да воли чисто [...] да може да даму посматра голу, и да чини све што захтева страст: да је држи у рукама (tener), да је грли (baiser), да је љуби (manejar)... све осим самог чина (lo fag). Жена се овим искушењем светила мужу за његово заповедање и тиранство, за његову грубу и нестрпљиву [сексуалну] жељу: човек 'ког би легла поред себе' морао је да се покорава свим њеним прохтевима а да не подлегне свом искушењу, осим у мери у којој је она желела и сама да му подлегне. Јер колико је љубавник кроз искушење стицао похвалу, толико је искушење бивало веће за њу и опасније за њену част. " (Нели 1958, у Маркал 1988: 225; наш превод)

Несумњиво, мало је витезова и дама успешно савладало овакву врсту теста „платонске” љубави. Према томе, примећује Ружмон, верност госпи у пракси дозвољава непоштовање брака и прељубу. Аутор ће, осим тога, у куртоазној књижевност, а посебно у текстовима који се односе на љубав Тристана и Изолде, открити необичан траг који ће довести до разоткривања суштине љубави-ероса: 
„[...] куртоазна љубав има необичну особину: колико је против брака толико је и против 'задовољења' љубави [...] Љубав није оно што се окреће стварности. [...] 'право страсти' у данашњем значењу дозволило би Тристану да преотме Изолду, пошто су испили напитак. Ипак, он је предаје краљу Марку [...] Какав је прави садржај легенде? Растајање љубавника? Да, али у име страсти и из љубави према самој љубави која их мучи, да би је распламсали и преобразили - науштрб своје среће и самог свог живота..." (Ружмон 2011: 28,30; курзив и три тачке ауторови)

Другим речима, Тристанов циљ није да преотме Изолду како би „живели срећно до краја живота” „у добру и у злу, док их смрт не растави", већ да ужива у самој жељи за њом. Ружмон нас подсећа да је јеврејски филозоф 12. века „Бен Давуд хвалио чедност због њене моћи да 'овековечи жељу”. (Ружмон 2011: 96) И „мистички љубавници у роману тежиће за све већом силином страсти, а не за њеним задовољењем. Што је њихова страст силнија, утолико их више одваја од сазданих ствари, а самим тим они кроз endura 1 лакше стижу до вољне смрти." (Ружмон 2011: 119; курзиви ауторови) Јер, ако љубавници ступе у брак, љубав ће постати део свакодневице, и нестаће чаролије и чежње које прате љубавне препреке:

„Радије ће се удаљити од оне са којом би сувише ризиковао да је гледа у скромној и једноставној светлости заједничког живота. [...] А кад су бића обузета страшћу принуђена да живе заједно, чаробни напитак убрзо престаје да делује." (Ружмон 2011: 306-307)

Укратко, та љубав, коју Ружмон дефинише као ерос, заправо је солипсистичка, и усмерена на своју слику у

$1 \mathrm{Tj.} \mathrm{искушења} \mathrm{која} \mathrm{морају} \mathrm{да} \mathrm{издрже.} \mathrm{У} \mathrm{сфери} \mathrm{љубави,} \mathrm{assag}$ представља облик ендуре (endura, тј. „искушење”). 
огледалу које „вољена” особа држи испред себе да се у њему огледамо. Ружмон подсећа на текстове иранских манихејаца, где мистик сусреће заносну девојку која му каже: „Ја сам ти [са̂м]!” (Ружмон 2011: 84) Другим речима, ја сам пројекција тебе самога:

„Тристан уопште не воли Изолду каква је у стварности, него је воли онакву каква у њему распаљује умилни жар жеље" (Ружмон 2011: 121).

Остајући тако у сфери свога ега и своје маште, ерос оставља вољену особу саму у материјалном свету патње и смрти, одбијајући да с њом доживотно и одано подели живот, и муку коју он носи - а управо је то смисао речи „док нас смрт не растави” - „from this day forward, for better for worse, for richer for poorer, in sickness and in health, to love and to cherish till death do us part [...]" (Књига општих молитви 2011: 436.)

Ерос одговара односу који је Мартин Бубер скраћено назвао ја-оно: то је однос према другом као према објекту, без истинске комуникације. Другу особу, доживљену као оно, ја не сагледава изнутра, као личност, већ споља, као ствар, као део непријатељског пејсажа који га окружује и опслужује. Овакав однос карактерише, примера ради, силовање.

С друге стране, љубав-агапе одговара односу ја-mu, односу два равноправна субјекта, два бића која се прожимају (библијско познағе) и изграђују у међусобном односу:

„Постајем ја кроз однос са тобом; кад постајем ја, ја кажем ти. Свако право живљење је сусретање.” (Бубер 1937:11; наш превод) $)^{2}$

2 "I become through my relation to the Thou; as I become I, I say Thou. All real living is meeting." 
Живот са људским бићем живот је без фотошопа уколико му допустимо да буде он, и не побегнемо после прве ране коју нам нанесе. Велбекови јунаци углавном не могу дуго да поднесу оног другог - одлазе чим Доријан Греј почне да стари уместо своје слике.

Једна мање позната епизода из окружења библијског цара Давида на сасвим експлицитан начин раскринкава суштину ероса. Наиме, један од Давидових синова по имену Амнон „разболео се од љубави” према својој полусестри Тамари: „И тужаше Амнон тако да се разболе ради Тамаре сестре своје” (2. Самуилова 13,2). Да би задовољио своју инцестуозну страст, Амнон се претвара да је болестан да би му Тамара донела да једе.

„А кад му пружи да једе, он је ухвати и рече јој: Ходи, лези са мном, сестро моја! А она му рече: Не, брате, немој ме осрамотити, јер се тако не ради у Израиљу, не чини то безумље. Куда бих ја са срамотом својом? А ти би био као који од најгорих људи у Израиљу. Него говори цару; он ме неће теби одрећи. Али је он не хте послушати, него савладавши је осрамоти је и облежа је. А после омрзе на ну Амнон веома, те мржна којом мржаше на юу беше већа од тубави којом је пре туббаше. И рече јој Амнон: Устани, одлази. А она му рече: То ће бити веће зло од оног које си ми учинио што ме тераш. Али је он не хте послушати. Него викну момка који га служаше, и рече му: Води ову од мене напоље, и закључај врата за њом." (стихови 11-17) ${ }^{3}$

Страст од које се „разболео” само је силна жеља, а не љубав према другом; то је однос ја-оно, не ја-тu, јер Тамара никада за Амнона није била ти, већ једино ова. Он ни на тренутак нема увид у Тамарину душу, јер њиме у потпуности доминира његова жеља, одбацивши чак и

3 Уколико није другачије назначено, сви библијски цитати потичу из превода Ђ. Даничића и В. Караџића. 
разум, чак и ауторитет оца и цара Давида, чак и ауторитет Бога и Божијих закона. Библијски писац се овде показује генијалним психологом бележећи да је Амнон истог тренутка када је добио што је желео силно замрзео девојку, „те мржна којом мржаше на юу беше већа од тьубави којом је пре льубьаше":

„Никада није презирао неко добро осим ако је било његово; његово срце гади се само оне среће коју је присиљен да има. А да му је ускраћена, јурнуо би у потрагу за њим, пошто стално мисли да ће наћи нешто боље, јер не воли оно што има! "4 (Ружмон 2011: 106; ауторов курзив)

Таква је природа љубави-ероса, који нема шта да да̂ осим жеље као императива:

„Нећу да испаднем животиња, / Ја не умем у двоје да трајем; / Ја сам ти љубавна сиротиња, / Узимам и ништа не дајем...” (Ђорђевић 19816, „Нећу да испаднем животиња”)

Зато ерос увек на крају остане сам - било зато што је остављен било зато што не уме „стати и остати”. Ружмон подсећа да је Ерос био деификација егоцентричне страсти. Међутим, већ су рани хришћански богослови јасно подвукли разлику између привидно симетричних исказа „Бог је љубав” (1. Јованова 4,8) и „Љубав је бог”. Постоји, наиме, дијаметрална супротност између библијског Бога чија је суштина љубав-дар (агапе), и Ероса, обожене људске страсти. У првом случају, врховни ауторитет је Бог, „богат” љубављу, док, у другом случају, човек своју личну страст поставља као божанство коме се морају покорити сви други ауторитети, укључујући и самог Бога.

4 Препознајмо Ерос дон Жуана и у речима једне популарне песме: „што видим то и пожелим, док није моје, ја немам мира”. И овде у средњем роду заменице што препознајемо однос ја-оно. 


\section{2. Агапе или тубав-дар}

За разлику од ероса, агапе за еталон не узима човека, већ Бога. Агапе је кључно обележје Божије личности, коју апостол Павле слика у 13. поглављу Прве посланице Коринћанима:

„Љубав је стрпљива, љубав је добра; љубав не завиди, не хвалише се, не прави се важна; није непристојна, не тражи своје, није раздражљива, не памти зло; не радује се неправди, а радује се истини; све штити, све верује, свему се нада, све трпи. Љубав никад не престаје." (стихови 4-8; Савремени српски превод)

Агапе је у суштини љубав која ужива не у узимању, већ у давању. Та љуб

ав, чија је најближа слика мајчинска љубав (управо она које ће Велбек бити судбоносно и неизлечиво лишен од раног детињства) излива себе у другог и не исцрпљује ce, него се умножава. Она ужива у умножавању себе у другима којима се посвећује, а њене ране, које јој наносе незахвалност, разочарање, одбацивање и презрење, брзо зацељују јер она не може да престане да се нада, да верује, да чека да се оно што је дала прими и умножи у вољеној особи, да семе које је посејала донесе рода.

Овакав опис љубави испрва обесхрабрује. Одакле нама људима таква љубав? Ко од нас није љубавна сиротиња? Одговор је једноставан: ако је агапе љубав-дар, онда она као таква оспособљава за љубав оне којима се дарује. Укратко - можемо волети агапе-љубављу ако уживамо у чињеници да смо и сами вољени на тај начин. Нико не мора да остане љубавна сиротиња - то је увек на крају лични избор.

Док Ружмон дефинише агапе пре свега као супротност еросу, К. С. Луис разматра четири грчка термина за 
различите врсте љубави: ерос, сторге, филиа и агапе. ${ }^{5}$ Укратко, ерос је љубав чија је основа сексуална привлачност, ${ }^{6}$ сторге је љубав међу члановима породице, филиа је пријатељска љубав, а агапе је Божија љубав. Луис на крају долази до два закључка. Први је да су у основи свих ових односа две темељне врсте љубави: љубав-потреба и љубав-дар. Једном љубављу дете воли мајку - јер је окренуто ка њој и од ње очекује ону другу врсту љубави, љубав-дар. Луис јасно примећује да се ове љубави надопуњују, али - што је далеко важније - да у сва она четири концепта љубави постоји различит удео дара и потребе, и, пре свега, да склад у љубави, посебно између мушкарца и жене, подразумева и љубав-потребу и љубавдар. И сам Бог Библије, који узвикује „љубим те љубављу вечном", истовремено се радује у узвраћеној љубави коју прима од људи:

„Господ Бог твој, који је усред тебе, силни, спашће те; радоваће ти се веома, умириће се у тьубави својој, веселиће се тебе ради певајући." (Софонија 3,17)

Савршена љубав подразумева потпуно давање и потпуно узимање:

„Нема љубави у личној слободи, у независности, то је напросто једна лаж, и то једна од најгорих која се може замислити; љубав постоји само у жељи за самопоништењем, за сједињењем, за нестанком индивидуе, у у

5 Савремена филолошка и херменеутичка истраживања инсистирају на значајним преклапањима концепата којима одговарају ова четири термина.

6 Ружмон и Луис не схватају ерос на исти начин. Док Ружмон наглашава егоцентричну и идеалистичку страну ероса, за Луиса је ерос напросто тип љубави која привлачи мушкарца и жену (дакле, сексуалност у најширем смислу). При томе саму физичку сексуалност Луис назива венером. 
једној врсти оног што се некад звало океанским осећағем, у у нечему што је у сваком случају било, бар у блиској будућности, осуђено на пропаст." (Велбек 2006б: 389 ориг.; наш превод и курзив)

Тако долазимо до тачке у којој се сједињују љубав-потреба („воли ме”) и љубав-дар („волим те”) - а то је припадање. „Остаћу слободан, нећу се везати, важно је само добро се зезати” (Ђорђевић 1981а, „Остаћу слободан”) поништава сваку могућност да такву срећу припадања, давања и узимања икада и на тренутак доживимо, а камоли да у њој трајемо.

Други је Луисов закључак да се све врсте људске љубави хране из извора Божије љубави. Без љубави-дара, без оспособљености да дајемо, све људске љубави пуцају или завршавају изопачењем и злостављањем. Ако људи не умеју да дају од себе и себе брату, родитељу, брачном другу, Богу - налазећи у том задовољство - или ће се однос претворити у насиље једне особе над другом, или ће се напросто прекинути.

Као што ћемо видети у наредном делу анализе, и Бора Ђорђевић и Мишел Велбек мајстори су описа свих нијанси сиве. И док у Велбековом делу тек на тренутак бљесне наговештај могућности љубавне среће, Пусто острво Боре Ђорђевића показује да је његово страдалничко, али доследно трагање за љубављу срећно завршено.

\section{3. Упоредна анализа поезије Боре Ђорђевића и романа Мишела Велбека}

У овом делу анализе, средишње место заузеће теме, мотиви и концепти заједнички љубавном песништву Боре Ђорђевића и романима Мишела Велбека. Анализа ће узети у обзир свеколики опус оба писца, с посебним нагласком на Пустом острву и Могућности острва. 
С обзиром на то да је љубавна поезија Боре Ђорђевића незаобилазни део популарне културе у Србији, као и на целом БСХЦ говорном подручју, док су романи Мишела Велбека, иако преведени на српски, познати релативном уском кругу читалаца, поређење два књижевна опуса извршићемо наводећи углавном Велбекове текстове и поредећи их с Бориним текстовима, које сви познајемо.

\section{1. Могућност острва}

Напуштен као дете од мајке, Велбек своју личну емотивну самоћу и глад претаче у романе који представљају потпуно јединствен спој бројних порнографских елемената, испуњених љубавним покушајима и погрешкама главних антијунака, са бриљантним филозофским анализама декаденције Запада - опет кроз призму љубавне беде и моралне голотиње протагониста емотивних и духовних драма које описује, али и сваковрсних друштвених појава. Било да је реч о Проширену подручја борбе (1994), Елементарним честицама (1998), Платформи (2001), Могућности острва (2005), Карти и територији (2010, за коју је, коначно, добио Гонкурову награду) или, чак, и Потчиюаваюу (2015) - Велбек на индивидуалном и друштвеном плану сецира морални и психолошки колапс западне цивилизације, у чијој је основи морални слом човека и друштва, односно одбацивање самопожртвовности у односу на друштво и верности у односу на другог човека.

Сам роман Могућност острва, испричан у првом лицу, развија своје наративно ткање у две хронолошке равни. У полазној и темељној наративној равни, наш савременик, средњовечни Данијел, цинични сатиричар и стенд-ап комичар, страсно трага за еротско-емотивним испуњењем. За Данијела, срећа, радост и блаженство римују се са богатством сексуалног живота. Међутим, 
у том трагању као главни непријатењ јавља се старост: док прву срећну везу с тек нешто млађом и присталом Изабелом уништава њена депресија због првих знакова старења, с друге стране, последња љубав његовог живота - двоструко млађа Естер - неће дуго остати с њим због његовог сопственог старења, али и неспособности ове припаднице младе генерације да прихвати секс као ишта друго осим угодног и необавезујућег спорта. Последње године прве временске равни смештене су у будућност у односу на нас савремене читаоце, и то у време легализовања еутаназије, за коју се у роману, попут већине остарелих и усамљених, одлучују најпре Изабела, а потом и Данијел, јер „неузвраћена љубав је”, ионако, „крволиптање” (Велбек 2006б: 243).

Друга временска раван романа израња из прве: Данијел се између прве и друге љубави среће са сектом елохимита (у нашој стварности тзв. раелијанаца - фp. Raёl), која својим члановима обећава бесмртност кроз клонирање. Вековима касније, видимо 23. по реду Данијеловог клона, Данијела24, како трагичну судбину свог претка и његове цивилизације бележи у дневник своје линије клонова усред постапокалиптичне будућности, у којој клонови лишени страсти и жеља немају физичке контакте, већ комуницирају преко интернета с удаљених тачака планете, заштићени од чопора подивљалих потомака људи „старе расе”. Дневник Данијела 24 показује да „научно” решење за људске патње није донело никакве друге резултате до још веће празнине и бесмисла постојања. Стога Данијел24 одлучује да напусти заштићене услове своје ограђене резиденције, упућујући се према океану у потрази за могућим острвом на ком ће моћи сусрести друге себи сличне људе и жене, жељан физичког контакта и искуства љубави које су древни људи познавали. У последњој сцени романа, Данијел24 не допире даље од обале, изнурен физички и душевно, 
очекујући смрт и не нашавши острво спаса, нити решење за патњу усамљеног људског бића.

\section{2. Сличности и разлике у Ђорђевићевој и Велбековој анализи туббави}

\subsection{1. Љубав и еротика}

Бора Ђорђевић је давно дефинисао доминантно тематско усмерење своје љубавне поезије:

„Ја нисам песник сломљеног срца/ Мирисних поља и цветнога маја/ Ја сам песник што воли да прца/ Мени инспирација долази из јаја" (Бора Чорба прича глупости, 1988)

Оваква позиција представља прву велику сличност између Ђорђевића и Велбека. Доминантно еротоцентрично надахнуће тешко је не приметити код Мишела Велбека од самог почетка. Као што смо поменули, у сваком од његових романа еротске деонице заузимају негде око трећине текста, а остале две припадају што нарацији, што разноврсним анализама друштвених феномена, које с благом иронијом подражавају научни дискурс. У позадини овако значајног присуства еротских, практично порнографских деоница, треба сагледати оно што и сам Велбек објашњава описујући љубавне јаде свог антијунака Бруна у Елементарним честииама: сексуална неуравнотеженост Бруна израз је патолошког, нездравог стања рањивости, недостатка самопоштовања, самоће, бесциљности и страха пред огољеном егзистенцијом. У сексу, Бруно је увек рањеник у потрази за утехом жене. Уместо провокације и егзибиционизма, сексуалност је код Велбека, нимало случајно нити неосновано, тесно везана за сам темељ личности и свест о себи и свом месту 
у друштву. Наслов романа није случајан: главни актери Елементарних честииа, а уосталом и других романа, закључно са Потчиюавағем, јесу друштвене монаде, усамљени негативно набијени електрони који су одавно излетели из путање коју им је друштво могло дати. Велбекови антијунаци не слажу се добро ни сами са собом, и не умеју да припадају. Ђорђевић у много збијенијој форми успева да прикаже овакве спорадичне сударе елементарних честица који никада не изазивају стварање простих једињења:

„Кад нађемо оправдање/ одглумимо осећање/ па спојимо наша тела/ то сам хтео, то си хтела [...] љубав цвета, а у ствари/ мужјак се са женком пари// и док измишљамо снове/ не знамо како се ко зове// Измењамо куртоазне/ поздраве и речи празне/ па свак' у свом таксију/ у своју галаксију” (Ђорђевић 2018, „Помало тужно”)

Та неспособност да препозна своју срећу посебно је видљива код Бруновог полубрата Мишела, научника коме љубав просто пролази испред носа а да прстом није мрднуо да је задржи, као и главном протагонисти Карте u територије, уметнику Џед Мартен. Ову двојицу, за разлику од Данијела, силно воле два најлепша и најпозитивнија женска лика код Велбека, Анабела и Олга, али они срећу нити препознају нити чувају. Тако се открива да за Велбекове мушкарце, велике губитнике, секс не доноси исцељење, нити их учи да воле и дају, већ представља само краткотрајну утеху, као добар џоинт, после кога ће врло брзо наступити нова криза.

Међутим, у стиховима Боре Ђорђевића не налазимо исту меру еротске зависности или апстинентског очаја као код Велбека. Дијахароно посматрана, Ђорђевићева љубавна поезија јесте сведочанство о бројним љубавним гресима, својим и туђим, које Ђорђевић сагледава час 
болно, час цинично, често подсмешљив и према самом себи, „[с]мешан, грешан и погрешан,/ Успешан и неуспешан,/ Несрећан и неутешан” (Ђорђевић 2018, „Смешан, грешан и погрешан”). У љубавној поезији, Ђорђевић је увек смело отворен и личан, па нам Пусто острво открива песника који је, за разлику од Велбекових антијунака, много пута на својој кожи осетио разлику између ероса и агапеа. Велбекови јунаци никад не увиђају да нас сексуалност усмерава једно на друго не зато да останемо стари и сами, већ да једно друго љубављу богатимо „док нас смрт не растави". Писац Пустог острва то је добро разумео.

Закључимо, ако Велбек и његови мушкарци дефинишу срећу као коитус, писац Пустог острва веома јасно показује еволуцију од раја као места пуног увек расположених хурија ка месту где га чека она права, једина.

\subsection{2. Острво}

Одавно Бора Чорба жели „[п]обећи негде, далеко, што даље, / где не требају пилуле за спавање..." (Ђорђевић 19816, „Побећи негде”) да се склони негде „далеко од разуздане гомиле". Пре њега, и пре Велбековог Данијела24, многи су чезнули за рајским острвом. У својој студији Une histoire du paradis. Le jardin des délices (1992), историчар Жан Делимо (Jean Delumeau) показује како је ширење цивилизације и потискивање природе постепено премештало претпостављену локацију библијског Раја све даље од људи. У католичком средњем веку, носталгија за рајем надахњује легенду о Срећним острвима и о острву светог Брендана. Аутори попут Исидора Севиљског (6-7. век), Жервеа из Тилбурија (13. век), Енглеза Бартоломеја

7 Наслов једног Хардијевог романа (Far from the Madding Crowd, 1874). 
(14. век) или Пјера од Ајија (Ymago mundi с почетка 15. века), преузимају легенду о Срећним острвима. Делимо показује да овакве легенде потичу још из античких времена. Данте, напомиње Делимо, приписује земаљском рају својства острва, а читав низ средњовековних путописа смешта рајску земљу на неко острво, недалеко од Шри Ланке или Индије. Не заборавимо ни келтску традицију, која говори о острву Авалону (нпр. код Џефрија од Монмута из 12. века, чије дело Historia regum Britanniae поставља темељ легенде о краљу Артуру).

У време великих морепловаца, од 16. века надаље, настају први путописи о егзотичним острвима Новог света чија флора и фауна несумњиво сведоче о рају који ће освајачи врло брзо претворити у пакао. Прва утопија модерног времена - она Морова (1516) - описује идеално острво. На таквој традицији, али и искуствима морепловаца и трговаца његовог времена, изградиће и Дефо најславнију острвску фикцију о Робинсону Крусоу (1719). Ипак, само неколико година касније, сатиричар Свифт начиниће од Дефоовог оптимизма карикатуру у Гуливеровим путованима (1726), у којима главни јунак обилази острвске земље пуне неразумних људи, од којих је свака све даље од раја.

У 20. веку, вредно је приметити да сам Велбек у Елементарним честииама драгоцене стране посвећује последњем роману Олдоуса Хакслија под именом Острво (1962), које управо описује нешто између дистопијског Врлог новог света, у коме су љубав и верност срамота, а промискуитет норма, и оног што би Хаксли назвао хордом, дивљаштва. Као и Велбеково дело, и Острво је заокупљено проблемом човекове природе и зла, које се пројицира на друштво и цивилизацију у целини. Нажалост, и Хакслијево „острво пусто је насељено густо”.

У Могућности острва Велбек развија роман у три фазе - од негативног, преко позитивног, ка коначном 
негативном: он полази од немилосрдног и циничног дисецирања свог доба да би кроз научно-фантастичну замисао о канарском острву Лансароте као месту постања нове људске расе - будућих људи-клонова које неће растрзати патње сваке врсте - показао коначни неуспех научног решавања проблема људске самоће. Одлука клона Данијела24 да одбаци бљутаву и отужну дистопијску нирвану једноличног и самотног постојања, и крене у потрагу за острвом на коме има људи као што је он, одлука да тако угрози будућност своје клонске линије и читав експеримент с новим човечанством, показује шта за Велбека острво симболизује: повратак на почетак, повратак аутентичном и потпуном контакту између људи, потребу за „океанским осећањем” једности с другим људским бићем. Није случајно што при крају романа, док преко врлети и литица путује ка обали океана, Данијел24 налази рукопис најутицајнијег античког дела о љубави, који ће многи, па и он, окривити за све илузије о љубави - Платонове Гозбе. Тако Велбек од Елементарних честииа преко Могућности острва затвара круг и враћа се на почетак, а да није нашао решење за condition humaine. Данијел24 није нашао рајско острво ни љубав, никада је није доживео нити разумео.

Да ли смо ми у томе успели? Да ли смо пронашли острво? Судећи по Пустом острву, Бора Ђорђевић јесте.

\subsection{3. Љубав, младост, старост}

Несумњиво централна теза у Велбековој Могућности острва већ је снажно присутна и у Елементарним честииама, а назире се и у Платформи:

„Нестанак нежности следи у стопу нестанак еротизма. Чисти однос не постоји, неко више јединство душа, нити било шта што може да личи на то, ни из далека. Кад 
нестане физичка љубав, све нестаје; суморна раздражљивост без дубље основе попуњава ток дана. Нисам гајио никакве илузије о физичкој љубави. Младост, лепота, снага: критеријуми физичке љубави су исти као и критеријуми нацизма." (Велбек 20066: 59)

Овакво схватање љубави неизоставно осуђује човека на патњу и самоћу, јер ограничава сексуалност на здравље и лепоту тела, и присуство либида. Међуодносу љубави и старости Велбек посвећује најболније и најлирскије странице романа. Годинама раније, а на свој духовити и самоиронишући начин, Бора Ђорђевић је у свега неколико редова сажео проблем који Велбек разлаже на неколико стотина страна:

„Ако те неко пита/ Најгоре од свих издајстава је / Кад те изда рођена кита / Кад нестане потенције / Нема егзистенције” (Ђорђевић 1988)

Овако ограничено схватање љубави можда пружа објашњење за сваковрсна самопонижења којима су склони мушкарци и жене који страхују од старења, у очајничком напору да сачувају право на љубав. Тако Данијелова срећа с Изабелом почиње да копни када она увиди да јој тело није више онако младо и еластично као пре, сматрајући - о, како жалосно! - да је тиме мање достојна Данијелове љубави. Видећи колико је за њега љубав синоним за активни сексуални живот, Изабела одлази у емотивну, а потом и у физичку смрт:

„Осећам, љубави, време ми истиче, / да ми се тло под ногама измиче, / ја своје полако завршавам / и немам права да те задржавам.” (Ђорђевић 2018, „Сам сам пао, сам се и убио") 
Схваћена као једини садржај и манифестација љубави, а неодвојива од биолошке младости која брзо пролази, телесна сексуалност постаје парадоксални извор самоће и бескрајне патње невољеног бића, уместо да буде извор доживотне радости и испуњења. С друге стране младост, поставши услов за љубав, прераста у опсесију свих узраста, која мучи и мушкарце и жене.

Ако упоредимо овакав однос према љубави, сексуалности и старости са дихотомијама Ружмона, Луиса и Бубера, увидећемо да он одговара еросу. Бежање од старости је знак да не пристајемо да волимо љубављу-даром, да бринемо о вољеној особи која стари и слаби. Међутим, истиче Велбек, иако тело стари и губи способност за физичку љубав, оно и даље жели додир, загрљај, топлину другог, а дух човеков, зрелији и свеснији себе и света, све силније воли што је старији:

„Не само да сексуална жеља не нестаје, него са годинама постаје све суровија, ${ }^{8}$ све болнија и незаситија [...] ; cosa mentale, жеља за жељом." (Велбек 2006б: 245)

Трагедија Велбекових јунака управо је у томе што ограничавају сексуалност на физичку љубав, уместо да јој допусте да прожме цело биће, осећања и мисли, и донесе срећу света и после младости. У Елементарним честицама, Кристијана, Брунова љубав(ница), остаје због болести непокретна, а Бруно, и сам празан, неспособан за љубав-дар, нема чиме да је утеши и увери у њену вредност и вољеност. Осећајући се безвредном и кривом што Бруну не може више да пружи задовољство, Кристијана се убија. С друге стране Данијел, после одласка Естер, по први пут и сам остављен, почиње да увиђа каква врста љубави чини људе срећнима на дуге стазе, али њега више нема ко тако да воли:

8 Наравно, и ову тврдњу треба узети условно. 
„Нема љубави у личној слободи, у независности, то је напросто једна лаж, и то једна од најгорих која се може замислити; љубав постоји само у жељи за самопоништењем, за сједињењем, за нестанком индивидуе, у у једној врсти оног што се некад звало океанским осећағем, у у нечему што је у сваком случају било, бар у блиској будућности, осуђено на пропаст." (Велбек 2005: 389)

Парадокс Данијеловог емотивног стања састоји се у томе што жели да буде вољен оном врстом љубави којом он сам није способан да воли другог. И док Велбекови мушкарци не умеју да у љубави трају, Пусто острво приказује човека који то жели у тој мери да се обраћа Богу:

„Можда ће молба да те зачуди,/ Ипак раба твојега пажњом удостоји,/ Помози ми да умрем у заблуди,/ Да права љубав постоји.” (Ђорђевић 2018, „Смешан, грешан и погрешан”)

Како са задовољством примећујемо, Бог је ову молитву и услишио.

\subsection{4. Ерос и романтизам - женске тьббавне илузије}

Како су Велбекови романи изразито „мушко писмо”, у њима се ретко јавља „књиженствени” поглед на љубав. Међутим, у поезији Боре Чорбе открива се и женски ерос, обично у другом лицу једнине („ти си...”). Овом приликом издвајамо, чини нам се, главни женски допринос неуспеху савремених веза - романтичну илузију:

„Ти си измишљала своје јунаке, / Који не пишке, који не каке./ Ти си креирала своје хероје,/ Да слепо слушају команде твоје.// Пропада свака романса нова,/ Јер тражиш свога принца из снова [...] // Хеј, не постоји Мистер Перфект,/ Хеј, свако има неки дефект,/ Хеј, човек од врлина грађен,/ Хеј, јесте тражен [sic !] није нађен.” (Ђорђевић 2018, „Мистер Перфект”) 
Бора Ђорђевић упозорава жене да се чувају - чега? Маске Ероса. Док у античком миту Ерос од Психе сакрива своје лепо лице, у романтичној илузији, која по Ружмону потиче од куртоазне љубави, Ерос је само лепа маска. Док архетип љубавника-заштитника, али несавршеног, свакако налазимо у односу библијског Адама и Еве, али и у нашим генима, остаје чињеница да је савршен мушкарац, као и савршена жена - велика лаж Ероса.

Ако у првој строфи Ђорђевићеве песме проналазимо опис љубавне реалности, друга строфа даје филозофски темељ судбоносне заблуде, чије су кључне речи романса и снови. У 19. веку, амерички трансценденталиста Р. В. Емерсон пише:

„Жене су више него ико елеменат и царство илузија. Очаране и саме, и оне очаравају. Оне гледају стварност кроз чаробне пределе Клода Лорена. А како би човек смео, и кад би могао, склонити кулисе, бинске ефекте и церемоније од којих оне живе? Област љубави је одвише пуна патетике и страдања, и њена атмосфера је увек склона фатаморгани.

Не треба нас много карати због наших рђавих бракова. Живимо међу халуцинацијама [...].” (Емерсон 2011:230)

Само бисмо једну замерку могли упутити Емерсону - ово је замка у коју упадају и мушкарци и жене. Само истина спојена с љубављу-агапеом чува нас од илузија.

Приказујући генезу трагедије Еме Бовари, Флобер се посебно обрушава на формирање њене личности и љубавног укуса упијањем романтичних 9 представа кроз литературу, слике и музику. Овде наводимо тек неколико реченица из дугог описа у ком Флобер иронично и врло

9 Занимљиво је, у овом контексту, проучити етимологију речи roman и romantique - које нас увек враћају управо на средњи век, куротазну љубав и Roman de la Rose - а посебно на модерне и савремене конотације ових речи. Тиме бисмо опет дошли до значења улепшаног, сентименталног и фиктивног. 
студиозно набраја призоре и мотиве из мноштва књижевних и сликарских извора оног времена:

„Биле су то све саме љубави, љубавници, љубавнице, прогоњене госпе што падају у несвест по усамљеним летњиковцима [...] мрачне шуме, узбуђена срца, заветовања, грцаји, сузе и пољупци, барке на месечини, славуји у шумарцима, лавовски храбра господа, благи као јагањци, пуни врлина каквих нема, увек лепо одевени, који сузе лију потоком. [...] Толико је волела да живи у каквом старом замку, као оне властелинке дугачког струка, које своје дане проводе испод уклесаних шиљатих сводова, налакћене на камен, с брадом у руци, гледајући како се у дну поља појављује витез с белом перјаницом јурећи на враном коњу.' (Флобер 2004: 34; курзив преузет)

Храњено љупким опсенама, нереално очекивање од љубави и од живота, представља по Флоберу последицу оваквог формирања љубавног укуса, која ће навести Ему да супруга Шарла, који је обожава, потцени и одбаци, а подлегне масци Ероса на лицу Родолфа, самољубивог и слаткоречовог кицоша. Када се пробуди из љубавног сна, потражиће излаз у смрти.

У Борино и Велбеково доба, жене и мушкарци се ретко убијају због љубави (радије убијају друге), али је патња иста, као и исход романтичне љубави - раскид и самоћа, иако и љубав и сексуалност постоје управо зато да би кроз живот повезивали двоје људи.

Приметимо, на крају, и једну спонтану игру речима у трећој строфи: perfect у енглеском значи и „савршен” и „прошли”. Како у језику, тако и у животу, заједнички живот претвара савршена очекивања у прошлост, а у садашњости се морамо суочити са стварним несавршенством и слабостима људи које волимо. Истовремено, уместо фаталног мирења с несавршенством, љубав-дар тежи да у будућности превазиђе своје болести и мане, како би усрећила вољену особу. Али, то је већ једна друга тема. 


\subsection{5. Безусловна тьубав - пас}

Као супротност егоцентричном еросу, који се код мушкараца и жена манифестује као жеља за доминацијом над другим („да слепо слуша команде твоје”), Велбек слика своју баку, која самозатајно подиже свог унука, и на крају несрећно страда док у баналној монотонији кухиње свом унуку ђаку спрема ручак. Не нашавши жену по мери, Велбеков Данијел читаоцима представља своје коначно откриће „безусловне љубави” - која не калкулише, која се с радошћу даје чак и кад је предмет љубави сасвим недостојан:

„Доброта, саосећање, верност, алтруизам, остају дакле близу нас као несхватљиве мистерије, које се, међутим, налазе у ограниченом простору телесног омотача једног пса." (Велбек 2006б: 62; наш курзив)

Величајући псећу љубав, и сам приватно нераздвојан од „најбољег човеког пријатеља”, Велбек цинично шиба мушкарце и жене. А Бора ће јасно: „пси ваљају, и понеки људи” јер:

„Човек греши, безгрешно је штене/ Па нека ми добри Господ суди/ Његов гнев нек' сручи се на мене,/ Више волим кучиће од људи.” (Ђорђевић 2018, „Пасји живот”)

Без пса - отелотворења безусловне и трајне љубави - Данијел не жели у бесмртност: читава линија његових клонова има пса, који је опет клон његовог пса Фокса. Ни Бора Ђорђевић није отишао на своје рајско острво без пса, баш као у чувеној песми Серђа Ендрига (1970): „Sarà come l'arca di Noè, il cane, il gatto, io e te!"

Сваком свој љубимац. 


\section{4. Закључак}

Упоредном анализом љубавне поезије Боре Ђорђевића и романа Мишела Велбека, показали смо бројније сличности и ређе разлике у њиховој анализи љубави као насушне, крхке и болне. Полазећи од троструке дихотомије - Ружмонове између ероса и агапеа, Луисове између љубави-дара и љубави-потребе и Буберове опозиције односа ја-ти и ја-оно - показали смо да оба уметника јасно сагледавају старење, себичност и романтичну илузију као основне препреке за постојаност љубави. Објаснили смо да и насловни мотив острва указује на рајско стање складне и постојане љубави за којом обојица трагају.

Ђорђевић много више, Велбек много ређе, указују на љубав-дар и однос ја-ти као на једини излаз:

„Физичка жеља, колико год била јака, никада није била довољна да изазове у мени љубав, могла је да достигне тај коначни стадијум тек када би је пратило, необичним нагомилавањем, саосећање са жељеним бићем; [...] ипак ми је одувек било потребно да поштујем да бих волео, и никада се, у суштини, нисам осетио савршено опуштено у сексуалној вези заснованој на чисто еротској привлачности и равнодушности према другом [...] ; не, никад се нисам одрекао људскости." (2006б: 172)

Тако се показује да љубавна срећа, и љубав уопште, не почива на физичком ужитку у коитусу - тај ужитак је само прати - нити љубав може да подразумева само ужитак, а не и бол. Премда Велбеков Данијел живи од коитуса до коитуса, његову самоћу и бесмисао таква ефемерна блаженства не могу да излече. Изабелина патња и Естерина себичност показују да срећне љубави нема без радосног посвећења своје слободе другоме. Уједно, и парадоксално, љубавна патња остарелих и одбачених потврђује да је сексуалност, више свега и пре свега, ментална категорија која не зависи од младости, као и да су 
љубав и сексуалност усмерене на заједничко постојање два бића, која кроз унакрсно смењивање љубави-потребе и љубави-дара превазилазе своју ограниченост.

Љубав-ерос, као љубавна илузија и прикривено самољубље, није манифестација исконске људске сексуалности већ једино сексуалне самоће, док је управо љубав-агапе, која једина излази из себе и продире у биће другог, право лице људске сексуалности, која сједињује, а не разједињује, која исцељује, а не рањава.

\section{5. Епилог}

Пре више година, разговарали смо с познаницом о љубави, разочарању и самоћи. У осетљивим средњим годинама, неопозиво сама после неколико емотивних неуспеха, она је наш разговор закључила горким речима: „Можеш да тражиш и бираш колико ти драго; како год окренеш, запашће те неки болесник." Ове речи су нас запрепастиле, грубе и наизглед неправедне, према животу и према људима. Ипак, време је показало да су ове речи истина, потпуна истина о нама. С тим што у болеснике увек треба урачунати и себе.

Сви смо ми болесници и рањеници, и као такве нас треба волети. Ко год то схвати, уклонио је највећу препреку за љубав и пријатељство с људима. Јер кад схватиш да нам свима бар нешто дебело фали, волећеш ближњег својега као самога себе. А срећа, та крхка али жилава срећа двају бића која се воле и повређују, али и кају и праштају, биће могућа, и то док нас смрт не растави. Мада је и тај проблем дугорочно решен. 


\section{Библиографија}

Библија 1991: Библија или Свето Писмо Старога и Новога завјета. Превео Стари завјет Ђура Даничић. Нови завјет превео Вук Стеф. Караџић, Београд: Библијско и инострано друштво.

Библија 2015: Свето Писмо. Савремени српски превод, Crete, IL: Bible League International.

Бубер 1937: M. Buber 1937, I and Thou, translated by Ronald Gregor Smith, Edinburgh: T. and T. Clark.

<http://ia700300.us.archive.org//load_djvu_applet.php?file=22/ items/IAndThou/IAndThou.djvu> (5.6.2018)

Велбек 2005: M. Houellebecq, La possibilité d'une île, Paris: Fayard. Велбек 2006а: М. Уелбек, Елементарне честище, превела Јасенка Томашевић, Београд: Плато.

Велбек 2006б: М. Уелбек, Могућност острва, превела Ивана Мисирлић, Београд: Плато.

Велбек 2013: М. Уелбек, Платформа, превела Зорица Бањац, Београд: ВООКА, едиција Западно од сунца.

Велбек 2015: М. Уелбек, Покораваюе, превео Владимир Д. Јанковић, Београд: ВООКА, едиција Западно од сунца.

Велбек 2015б: М. Уелбек, Проширене подручја борбе, превео Владимир Д. Јанковић, Београд: ВООКА, едиција Западно од сунца.

Делимо 1992: J. Delumeau, Une histoire du paradis. Paris: Fayard.

Емерсон 2011: Р. Валдо Емерсон, Управтьане животом, превела Исидора Секулић, Београд: Партенон.

Емерсон 1888: R. W. Emerson, The Conduct of Life, Boston, New York: Houghton, Mifflin and company. < https://www.loc.gov/ item/03020722/> (20.6.2018)

Ђорђевић 2018: Б. Ђорђевић, Пусто острво, Андрићград: Андрићев институт.

Књига општих молитви 2011: The Book of Common Prayer. Texts of 1549, 1559, and 1662, Oxford: Oxford University Press.

Луис 1960: C. S. Lewis, The Four Loves, London : Geoffrey Bles.

Луис 2012: C. S. Lewis, Četiri ljubavi, превела Марија Павлин, Загреб: Вербум. 
Маркал 1988: J. Markale, L'amour courtois ou le couple infernal, Paris : Imago.

Нели 1958: R. Nelli, De l'affèrement par le sang à "l'épreuve" des corps, y: R. Nelli (dir.), Les Cahiers du Sud : Sur l'amour provençal, $\mathrm{n}^{\circ} 347$.

Нели 1972: R. Nelli, Les Cathares, Paris : Grasset.

Ружмон 2011: Д. де Ружмон, Љубав и Запад, превео Милан Комненић, Београд: Службени гласник.

Самарџија-Грек 2014: Tatjana Samardžija Grek, Mesijanstvo nauke u jednom romanu Mišela Velbeka: ljubav, smrt, samoća. $\mathrm{Y:}$ Б. Димитријевић (ур.). Тематски зборник радова [са трећег међународног научног скупа Наука и савремени универзитет, 2013]. [Том 3], Савремене парадигме у науци и научној фантастищи, (Библиотека Научни скупови, том 3), Ниш: Филозофски факултет, 300-319.

Самарџија-Грек 2012: Tatjana Samardžija-Grek. Les perspectives temporelle et narrative dans La carte et le territoire de Michel Houellebecq. Y: J. Novaković (ur.). Les études françaises aujourd'hui, La représentation de l'espace dans les littératures française et francophone, Le français: de la forme au sens et inversement. Beograd: =Belgrade: Филолошки факултет Универзитета у Београду: =Faculté de Philologie de l'Université de Belgrade: Друштво за културну сарадњу Србија-Француска: =Association de coopération culturelle Serbie-France, 237-248.

Флобер 2004: Г. Флобер, Госпођа Бовари, превела Цвета Котевска. Београд: Политика/Народна књига.

\section{Дискографија}

Ендриго 1970: S. Endrigo, L’arca di Noè, Milano: Fonit Cetra. Ђорђевић 1988: Б. Ђорђевић, Бора Чорба прича глупости, Марибор: Helidon.

Ђорђевић 1981а: Б. Ђорђевић, Покварена машта и прғваве страсти, Београд: ПГП РТБ.

Ђорђевић 1981б: Б. Ђорђевић, Мртва природа, Београд: ПГП РТБ. Чолић 2013: 3. Чолић, Зар се нисмо схватили, Ватра и барут, Београд: City Records. 
Tatjana Samardžija

\section{THERE IS AN ISLAND - LOVE IN THE POETRY OF BORA ĐORĐEVIĆ AND IN THE NOVELS OF MICHEL HOUELLEBECQ}

Through a comparative analysis of themes and motives associating the love poetry of the "Serbian Bob Dylan" Bora Đorđević and the fiction of the French novelist Michel Houellebecq, with an emphasis on Đorđevićs collection of poetry Pusto ostrvo (i.e. "Desert Island", 2017) and Houellebecq's novel La possibilité d'une ile (Engl. transl. The Possibility of an island, 2005), we aim at showing number of similarities in their approach to the problem of frailty and pain of love. Both authors explore the causes of and the solution for the antagonism between egoism and need for love in a couple. From the theoretical point of view, our comparison hinges on three basic dichotomies : eros/ agape (D. de Rougemont, L'Amour et l'Occident, 1960 ; Engl. Trans. Love in the Western World, 1940), love-need/ love-gift (C. S. Lewis, The Four Loves, 1960) and I-Thou/ I-It (Martin Buber, Ich und Du, 1923 ; Engl. transl. I and Thou, 1937). Confronting the many aspects of love offered by the poet and the novelist, we argue that they both consider ageing, selfishness and romantic illusion as the major impediments to a lasting love. Love's labor is always lost when reduced to sexual intercourse, which "has all too short a date", so that the rest of life turns into solitude and pain. Still, the crucial trigger of love misery is in us: the self-centered love-eros is a beggar who takes pleasure in its own desire, whereas sexuality is that fundamental and life-long instinct of transcending the limits of self by knowing the other and belonging to him/her. Considered in such a context, the motif of island represents a new Eden where love and joy of two blended individualities become possible.

Key words: island, eros, agape, Bora Đorđević, Michel Houellebecq, Denis de Rougemont, C. S. Lewis. 